ROCZNIKI PEDAGOGICZNE

Tom 13(49), numer $3-2021$

DOI: http://doi.org/10.18290/rped.21133.7

\title{
TOŻSAMOŚĆ OSOBISTA I JEJ ZWIĄZEK Z AKCEPTACJĄ SIEBIE JAKO OSOBY GŁUCHEJ - BADANIA NAD DOROSŁYMI UŻYTKOWNIKAMI IMPLANTÓW ŚLIMAKOWYCH Z GŁUCHOTĄ PRELINGWALNĄ
}

\section{WPROWADZENIE}

W badaniach nad osobami g/Głuchymi ${ }^{1}$ ważne miejsce zajmuje problematyka tożsamości skupiona w przeważającej większości wokół tożsamości społeczno-kulturowej Głuchych, traktowanych jako mniejszość językowa (język migowy) i kulturowa (kultura Głuchych) (Leigh, 2009, 2010). W szerszym ujęciu badania te obejmują tożsamość społeczną osób g/Głuchych, w której uwzględnia się poczucie przynależności do różnych grup osób g/Głuchych i słyszących (Wojda, 2010; Dammeyer, Chapman, 2017).

Tożsamości osobistej osób głuchych poświęca się stosunkowo niewiele miejsca, choć można powiedzieć, że jest ona fundamentalna w osobowym rozwoju człowieka. Jak mówią Maria Jarymowicz i Anna Szuster, reprezentantki poznawczego ujęcia tożsamości: „Tworzy się tylko ograniczona jawna reprezentacja własnej osoby, a z niej wyłania się coś, co podmiot uznaje za najbardziej dla siebie charakterystyczne - tożsamość indywidualna"

Dr n. hum. JoAnna Kobosko - Instytut Fizjologii i Patologii Słuchu; adres do korespondencji: ul. M. Mochnackiego 10, 02-042 Warszawa; e-mail: jkobosko@poczta.onet.pl; ORCID: https://orcid.org/0000-0001-8939-4381.

${ }^{1}$ Pisownia z wielkiej litery „G” odnosi się wzorem tradycji amerykańskiej do członków mniejszości językowej (komunikującej się w języku migowym) i kulturowej (tworzącej kulturę Głuchych), natomiast z małej litery „g" do osób głuchych audiologicznie, tj. posiadających ubytek słuchu w stopniu głębokim lub znacznym. Należy w tym miejscu dodać, że na świecie pojawia się tendencja uznawania tego rozróżnienia za przestarzałe w obliczu m.in. ogromnego zróżnicowania populacji osób głuchych w aspekcie środowiskowym, językowym, edukacyjnym, tożsamościowym czy kulturowym (zob. Marschark, Zettler, Dammeyer, 2017). 
(Jarymowicz, Szuster, 2015, s. 227). Zdaniem Marii Jarymowicz tożsamością osobistą jest ujmowanie własnej osoby w terminach cech, które uznaje się za definiujące tę tożsamość, a za jej „wyróżnik” uważa się percepcję odrębności Ja-Inni (Jarymowicz, 1989; za: Krzyżewski, Kazberuk, 2000). W ujęciu emotywno-refleksyjnym „Tożsamość osobistą można uznać za unikatowy, specyficzny dla jednostki i względnie stabilny sposób określania, rozumienia i doświadczania siebie, będący wyrazem dążenia do osiągnięcia osobistej autonomii i wewnętrznej integracji” (Kwapis, Brygoła, 2013). Michael J. Carter i Danielle Mireles (2016) wymieniają tożsamość osobistą (ang. person lub personal identity) obok tożsamości związanej z pełnionymi rolami, np. pracownika czy rodzica, a także różnymi rodzajami tożsamości społecznej/grupowej. W opinii tych autorów tożsamość osobistą tworzą posiadane i tworzone przez daną osobę znaczenia, które definiują, kim ona jest jako unikalna indywidualność. Przykładem tożsamości osobistej jest np. tożsamość moralna, tożsamość jako osoby inteligentnej czy tożsamość jako osoby głuchej tworzona ze względu na jej atrybut, jakim jest głuchota (Carter, Mireles, 2016). W przyjętym w pracy podejściu interpersonalnym tożsamość osobowa, mieszcząca w sobie tożsamość osobistą (jako osoby głuchej), to doświadczanie siebie w relacjach z innymi ludźmi, w tym także w wymiarze głuchota v. słyszenie (Zalewska, 1998, 2009a, 2009b; Kobosko, 2007a, 2007b, 2009, 2010).

Tożsamość osobista osób głuchych była jak dotąd przedmiotem nielicznych badań. $Z$ tych dotychczas przeprowadzonych wynika, że młodzi głusi dorośli w wieku od 18 do 22 lat, komunikujący się biegle w języku fonicznym lub naturalnym języku migowym, doświadczają siebie jako mniej „złośliwych”, „słyszących”, „leniwych”, „brzydkich”, a bardziej „niepełnosprawnych”, „grzecznych”, „wrażliwych”, jak i posiadających w większym nasileniu cechy negatywne ogółem w porównaniu z osobami słyszącymi w podobnym wieku. Cechami o największym nasileniu w tej grupie były: „dobry” i „wrażliwy”, natomiast „wrażliwy”, „,dobry” i „słyszący” wśród badanych osób słyszących. Najmniejsze nasilenie otrzymano w zakresie cech: „słyszący” i „głupi” wśród badanych osób głuchych oraz „głupi” i „niepełnosprawny" w grupie słyszących (Kobosko, 2007a, 2009). Z kolei z innych polskich badań nad młodzieżą głuchą młodszą wiekiem, będącą w wieku od 16 do 19 lat wynika, że jej tożsamość osobista różni się znacząco względem młodzieży słyszącej - wyniki pokazują, że młodzież ta posługuje się w opisie siebie i tego, kim jest, częściej takimi kategoriami, jak: stan cywilny, ciało i wygląd zewnętrzny, upodobania i aktywność, przyjaźń i relacje z innymi, 
sytuacje społeczne i osobiste, cechy osobowości negatywne i neutralne (Kossewska, Brdej, 2008). Natomiast badacze Michael J. Carter i Danielle Mireles (2016), którzy weryfikowali związek tożsamości osobistej osób głuchych z nasileniem depresyjności, otrzymali, że większy stopień trudności, jakiego doświadczają osoby głuche w byciu sobą (tj. osobą głuchą) w różnych sytuacjach społecznych wiąże się $\mathrm{z}$ większym nasileniem doświadczanych objawów depresyjnych.

Akceptacja siebie jako osoby głuchej często pojawia się w rozważaniach o osobowej tożsamości jako osoby głuchej (Zalewska 1998, 2009a, 2009b), wskazując, że trudności w akceptacji siebie, jako osoby głuchej, nieuchronnie wiążą się z problemami wokół własnej tożsamości, jak ma to miejsce w opisywanym przez Marinę Zalewską klinicznym studium przypadku dziewczyny głuchej (Zalewska, 2009b). Akceptację siebie jako osoby głuchej można zdefiniować za Michaelem Rosenbergiem (1965, za: Dzwonkowska, Lachowicz-Tabaczek, Łaguna, 2008) jako pozytywny stosunek do siebie także jako osoby głuchej. Okazuje się być ona dodatnio silnie skorelowana z samooceną globalną (Kobosko, 2018), a także, lecz ujemnie z psychologicznym dystresem (de Graaf, Bij1, 2002). Wątek akceptacji siebie jako osoby głuchej obecny jest dość często w badaniach jakościowych nad osobami głuchymi, gdyż stanowi niezwykle ważny problem w ich psychospołecznym funkcjonowaniu (Kobosko, 2010, 2018; Podgórska-Jachnik, 2013; Wolsel, Clark, van der Mark, 2017; Wrześniewska-Pietrzak, 2017). Trudnościom związanym z akceptacją siebie, jako osoby głuchej, często towarzyszy doświadczanie samotności, osamotnienia i izolacji społecznej, nie tylko w rodzinie pochodzenia (Kobosko, 2007b, Podgórska-Jachnik, 2013; Marganiec, 2014), lecz także w grupach rówieśniczych wśród słyszącej większości (Zębik, 2007; Kobosko, 2010; Podgórska-Jachnik, 2013; Dryżałowska, 2016; Wolsel, Clark, van der Mark, 2017). Akceptacja siebie, jako osoby głuchej, stanowi punkt wyjścia do akceptacji społecznej, na co wskazują badacze samoakceptacji w aspekcie różnych niepełnosprawności (Li, Moore, 1998).

$\mathrm{W}$ prezentowanych badaniach wiodącym stało się zagadnienie tożsamości osobistej osób dorosłych z głuchotą prelingwalną, korzystających z implantu ślimakowego (bądź implantów) od dzieciństwa, adolescencji lub okresu dorosłości i jej związku z akceptacją siebie jako osoby głuchej. W Polsce, jak i na świecie, nie ma jak dotąd badań na podjęty temat. 


\section{CEL BADAŃ}

Celem badań jest odpowiedź na pytanie o to, jaka jest tożsamość osobista określana w kategoriach cech, a także akceptacja siebie jako osoby głuchej u osób głuchych prelingwalnie, które są użytkownikami implantów ślimakowych. Jednakże zasadniczy problem badawczy dotyczy weryfikacji istnienia związku między tożsamością osobistą a akceptacją siebie jako osoby głuchej w badanej grupie.

\section{METODY BADAŃ}

\section{Uczestnicy badań}

W badaniach wzięły udział 84 osoby dorosłe z głuchotą prelingwalną o ubytku słuchu według klasyfikacji BIAP znacznym lub głębokim, w wieku od 18 do $45(\mathrm{M}=27,65 ; \mathrm{SD}=7,68)$ lat, spośród których kobiety stanowiły 52 osoby (61,9\%). Osoby zakwalifikowane do badań w ocenie surdologopedycznej posiadały wysokie kompetencje językowe w języku polskim fonicznym. Wszyscy byli użytkownikami jednego $(n=68)$ lub dwóch $(n=16)$ implantów ślimakowych (CI) od dzieciństwa, adolescencji lub dorosłości. Wiek, w którym wszczepiono im pierwszy CI, mieścił się w przedziale od 2 do 42 lat $(\mathrm{M}=16,42$; $\mathrm{SD}=10,32)$, a wiek $\mathrm{w}$ momencie drugiego $\mathrm{CI}$ od 14 do 39 lat $(\mathrm{M}=21,94$; $\mathrm{SD}=6,67)$. Natomiast czas korzystania z pierwszego CI wynosił od 0,7 do 25 lat $(\mathrm{M}=11,34, \mathrm{SD}=5,36)$, drugiego od 0,1 do 10 lat $(\mathrm{M}=3,96, \mathrm{SD}=2,69)$. W związku małżeńskim (partnerskim) pozostawało $30(35,7 \%)$ osób, w tym z partnerem (współmałżonkiem), który nie słyszy lub nie dosłyszy 10 osób (33\%). Wykształcenie średnie posiadało $36(42,9 \%)$ osób, wyższe i półwyższe 47 (56\%) osób, jedna z badanych nie podała tej informacji. Osoby pracujące stanowiły $48(57,1 \%)$ osób, uczące się lub studiujące 31 (36,9\%) osób, natomiast $5(6 \%)$ osób nie uczyło się, ani nie studiowało. Na pytanie o subiektywną ocenę znajomości języka migowego przez badanych 21 (25\%) osób odpowiedziało, że zna ten język dobrze, 26 (31\%) osób oceniło znajomość tego języka jako „trochę lub słabo”, a 37 (44\%) osób napisało, że nie zna go wcale.

\section{Narzędzia badawcze}

Kwestionariusz ,JJa-Inni” - stanowi zmodyfikowaną na potrzeby wcześniejszych badań nad młodzieżą głuchą wersję Kwestionariusza Cech wg M. Ja- 
rymowicz (Kobosko, Szuchnik, Wojda, 2004; Kobosko, 2007a, 2009). Przeznaczony jest do pomiaru nasilenia wybranych 20 cech człowieka i spostrzegania ich na wymiarze „podobny-niepodobny” do innych. Obejmuje 10 cech pozytywnych (np. „dobry”, „wrażliwy”, „lubiany”) i 10 cech negatywnych (np. „głupi”, „nerwowy”, „,niepełnosprawny”). Osoba badana zaznacza na siedmio punktowej skali, ,jaka jest w porównaniu z innymi ludźmi”. Gdy uważa, że jest „tak samo”, np. „wrażliwa”, jak inni ludzie, wówczas zaznacza 4 punkty, gdy „dużo mniej” wrażliwa, zaznacza 1 punkt, a gdy „dużo bardziej” wrażliwa, to zaznacza 7 punktów. Możliwe są też odpowiedzi pośrednie, punktowane odpowiednio jako 2 lub 3 oraz 5 lub 6. Obliczyć można także wynik dla wszystkich cech negatywnych razem i wszystkich cech pozytywnych razem, a stanowi on średnią odpowiednio: wszystkich cech negatywnych lub pozytywnych. Wyniki omawianego kwestionariusza służą do opisu tożsamości osobistej badanych.

Akceptacja siebie jako osoby gluchej - osoba badana zaznacza na skali wizualno-analogowej (VAS), której krańce oznaczono od 1 do 10, na ile akceptuje siebie jako osobę głuchą. Linia ta miała długość $161 \mathrm{~mm}$, a pomiaru akceptacji dokonywano w milimetrach, następnie przeliczano na skalę procentową. Ten sposób pomiaru zaproponowano już wcześniej (Kobosko, 2018; Kobosko, Geremek-Samsonowicz, Kochański, Pankowska, Skarżyński, 2019).

\section{Procedura badań}

Badania przeprowadzone zostały metodą wysyłki pocztowej. Otrzymano wskaźnik odpowiedzi zwrotnych wynoszący $32,2 \%$.

\section{WYNIKI*}

Tożsamość osobista osób głuchych z implantem ślimakowym (CI) (Kwestionariusz „Ja-Inni”)

Tożsamość osobistą badanych opisują wyniki zawarte w tabeli 1 oraz przedstawione na wykresie 1. Najwyżej oceniają siebie w porównaniu z innymi ludźmi w wymiarze (cesze) „wrażliwy” i „dobry”, najniżej w cesze „słyszący” i „głupi”. W grupie tej ma miejsce polaryzacja pozytywna w percepcji siebie, a więc istotna przewaga cech pozytywnych razem nad cechami negatywnymi razem $(\mathrm{p}<0,001)$.

\footnotetext{
* Autorka dziękuje inż. Bartoszowi Kochańskiemu za pomoc w obliczeniach statystycznych.
} 
Tabela 1. Kwestionariusz Ja-Inni - cechy w kolejności rosnącej - od cech o najmniejszym nasileniu do cech o największym nasileniu - w grupie osób z głuchotą prelingwalną, korzystających z CI (n=84) z uwzględnieniem stopnia akceptacji siebie jako osoby głuchej: niskiego (AN), średniego (AS) i wysokiego (AW).

\begin{tabular}{|l|l|l|l|l|l|l|l|}
\hline & & & & & & \\
\hline
\end{tabular}




\begin{tabular}{|c|c|c|c|c|c|c|c|}
\hline Nieśmiały & $\begin{array}{l}3,98 \\
(1,68)\end{array}$ & Nerwowy & $\begin{array}{l}4,16 \\
(1,60)\end{array}$ & $\begin{array}{l}\text { Towa- } \\
\text { rzyski }\end{array}$ & $\begin{array}{l}4,06 \\
(1,21)\end{array}$ & Leniwy & $\begin{array}{l}3,54 \\
(1,67)\end{array}$ \\
\hline Towarzyski & $\begin{array}{l}4,01 \\
(1,33)\end{array}$ & Taktowny & $\begin{array}{l}4,20 \\
(1,04)\end{array}$ & $\begin{array}{l}\text { Atrakcyjny } \\
\text { fizycznie }\end{array}$ & $\begin{array}{l}4,06 \\
(0,98)\end{array}$ & $\begin{array}{l}\text { Niepełno- } \\
\text { sprawny }\end{array}$ & $\begin{array}{l}3,89 \\
(1,71)\end{array}$ \\
\hline $\begin{array}{l}\text { Niepeł- } \\
\text { nosprawny }\end{array}$ & $\begin{array}{l}4,17 \\
(1,63)\end{array}$ & Wesoły & $\begin{array}{l}4,24 \\
(1,13)\end{array}$ & $\begin{array}{l}\text { Niepel- } \\
\text { nosprawny }\end{array}$ & $\begin{array}{l}4,23 \\
(1,43)\end{array}$ & $\begin{array}{l}\text { Atrak- } \\
\text { cyjny } \\
\text { fizycznie }\end{array}$ & $\begin{array}{l}4,18 \\
(1,33)\end{array}$ \\
\hline $\begin{array}{l}\text { Atrakcyjny } \\
\text { fizycznie }\end{array}$ & $\begin{array}{l}4,21 \\
(1,28)\end{array}$ & $\begin{array}{l}\text { Pomy- } \\
\text { słowy }\end{array}$ & $\begin{array}{l}4,28 \\
(1,54)\end{array}$ & Taktowny & $\begin{array}{l}4,32 \\
(1,05)\end{array}$ & $\begin{array}{l}\text { Towa- } \\
\text { rzyski }\end{array}$ & $\begin{array}{l}4,29 \\
(1,18)\end{array}$ \\
\hline Szczęśliwy & $\begin{array}{l}4,25 \\
(1,34)\end{array}$ & $\begin{array}{l}\text { Niepełnosp } \\
\text { rawny }\end{array}$ & $\begin{array}{l}4,40 \\
(1,80)\end{array}$ & Lubiany & $\begin{array}{l}4,32 \\
(0,98)\end{array}$ & Taktowny & $\begin{array}{l}4,36 \\
(1,25)\end{array}$ \\
\hline Taktowny & $\begin{array}{l}4,30 \\
(1,11)\end{array}$ & $\begin{array}{l}\text { Atrakcyjny } \\
\text { fizycznie }\end{array}$ & $\begin{array}{l}4,44 \\
(1,58)\end{array}$ & Szczęśliwy & $\begin{array}{l}4,35 \\
(1,25)\end{array}$ & Lubiany & $\begin{array}{l}4,43 \\
(1,07)\end{array}$ \\
\hline Lubiany & $\begin{array}{l}4,43 \\
(113)\end{array}$ & Samotny & $\begin{array}{l}4,48 \\
(1,66)\end{array}$ & Nieśmiały & $\begin{array}{l}4,39 \\
(1,33)\end{array}$ & $\begin{array}{l}\text { Pomy- } \\
\text { słowy }\end{array}$ & $\begin{array}{l}4,50 \\
(1,11)\end{array}$ \\
\hline Pomysłowy & $\begin{array}{l}4,44 \\
(1,17)\end{array}$ & Lubiany & $\begin{array}{l}4,56 \\
(1,39)\end{array}$ & Wesoły & $\begin{array}{l}4,39 \\
(1,02)\end{array}$ & $\begin{array}{l}\text { Szczę- } \\
\text { śliwy }\end{array}$ & $\begin{array}{l}4,57 \\
(1,10)\end{array}$ \\
\hline Wesoły & $\begin{array}{l}4,45 \\
(1.10)\end{array}$ & Nieśmiały & $\begin{array}{l}4,60 \\
(1,91)\end{array}$ & $\begin{array}{l}\text { Pomy- } \\
\text { słowy }\end{array}$ & $\begin{array}{l}4,52 \\
(0,85)\end{array}$ & Wesoły & $\begin{array}{l}4,71 \\
(1,15)\end{array}$ \\
\hline Dobry & $\begin{array}{l}4,90 \\
(1,07)\end{array}$ & Dobry & $\begin{array}{l}5,12 \\
(1,01)\end{array}$ & Dobry & $\begin{array}{l}4,90 \\
(1,22)\end{array}$ & Dobry & $\begin{array}{l}4,71 \\
(0,94)\end{array}$ \\
\hline Wrażliwy & $\begin{array}{l}5,23 \\
(1,10)\end{array}$ & Wrażliwy & $\begin{array}{l}5,60 \\
(1,19)\end{array}$ & Wrażliwy & $\begin{array}{l}5,16 \\
(1,07)\end{array}$ & Wrażliwy & $\begin{array}{l}4,96 \\
(1,00)\end{array}$ \\
\hline $\begin{array}{l}\text { Cechy } \\
\text { negatywne } \\
\text { razem }\end{array}$ & $\begin{array}{l}3,45 \\
(0,93)\end{array}$ & $\begin{array}{l}\text { Cechy } \\
\text { negatywne } \\
\text { razem }\end{array}$ & $\begin{array}{l}3,83 \\
(1,05)\end{array}$ & $\begin{array}{l}\text { Cechy } \\
\text { negatywne } \\
\text { razem }\end{array}$ & $\begin{array}{l}3,45 \\
(0,82)\end{array}$ & $\begin{array}{l}\text { Cechy } \\
\text { negatywne } \\
\text { razem }\end{array}$ & $\begin{array}{l}3,11 \\
(0,84)\end{array}$ \\
\hline $\begin{array}{l}\text { Cechy } \\
\text { pozytywne } \\
\text { Razem }\end{array}$ & $\begin{array}{l}4,27 \\
(0,68)\end{array}$ & $\begin{array}{l}\text { Cechy } \\
\text { pozytywne } \\
\text { Razem }\end{array}$ & $\begin{array}{l}4,25 \\
(0,85)\end{array}$ & \begin{tabular}{|l|} 
Cechy \\
pozytywne \\
Razem
\end{tabular} & $\begin{array}{l}4,22 \\
(0,53)\end{array}$ & $\begin{array}{l}\text { Cechy } \\
\text { pozytywne } \\
\text { Razem }\end{array}$ & $\begin{array}{l}4,35 \\
(0,68)\end{array}$ \\
\hline
\end{tabular}

$\mathrm{M}$ - średnia; SD - odchylenie standardowe 
Wykres 1. Wyniki Kwestionariusza „Ja-Inni” u osób z głuchotą prelingwalną z CI - cechy negatywne i cechy pozytywne w grupach o różnym stopniu akceptacji siebie jako osoby głuchej: niskim (AN), średnim (AS) i wysokim (AW).

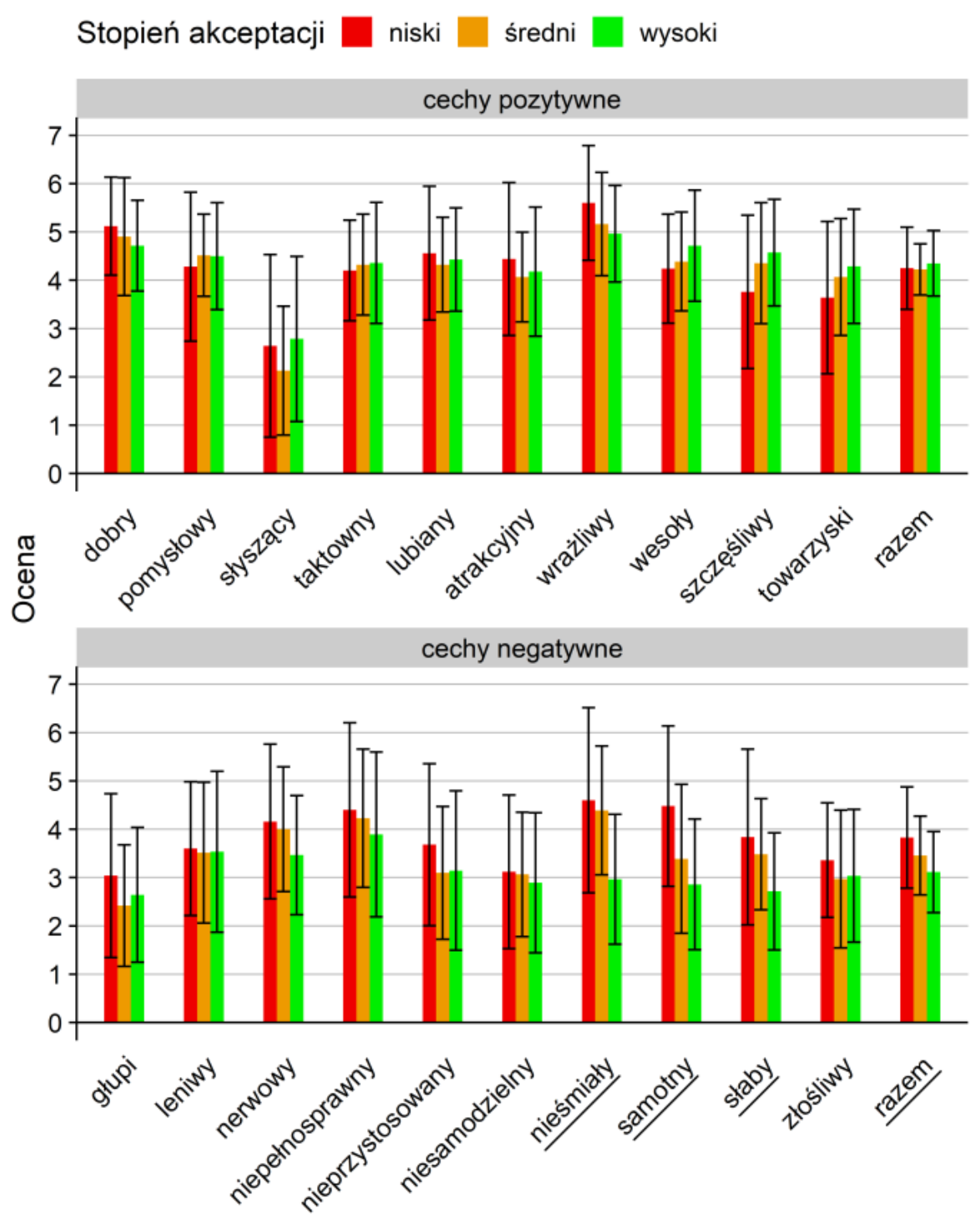

Akceptacja siebie jako osoby głuchej (VAS)

Pomiar tej zmiennej z wykorzystaniem skali VAS został już wcześniej opisany (Kobosko, Geremek-Samsonowicz, Kochański, Pankowska, Skarżyński, 
2019). Wyniki uzyskane przez osoby z głuchotą prelingwalną z CI w pomiarze akceptacji siebie jako osoby głuchej zostały przeliczone na skalę procentową i przypisane do 3 grup o wysokim (AW), średnim (AS) i niskim (AN) stopniu akceptacji według empirycznie ustalonych kryteriów tego podziału. Ustalono, że niska akceptacja siebie, jako osoby głuchej, mieści się w przedziale wyników od 0 do $65 \%$, średnia akceptacja w przedziale od powyżej $65 \%$ do $92 \%$, a wysoka akceptacja siebie jako osoby głuchej znajduje się w zakresie od powyżej $92 \%$ do $100 \%$. Dla każdej z tak otrzymanych podgrup obliczono średnią (M) i odchylenie standardowe (SD), a także sprawdzono normalność rozkładu wyników (tabela 2).

Tabela 2. Akceptacja siebie jako osoby głuchej: niska (AN), średnia (AS), wysoka (AW) u osób dorosłych z głuchotą prelingwalną z CI.

\begin{tabular}{|l|c|c|c|c|}
\hline & $\begin{array}{c}\text { Akceptacja } \\
\text { niska (AN) } \\
\text { M(SD) } \\
\mathbf{n = 2 5}\end{array}$ & $\begin{array}{c}\text { Akceptacja } \\
\text { średnia (AS) } \\
\text { M(SD) } \\
\mathbf{n = 3 1}\end{array}$ & $\begin{array}{c}\text { Akceptacja } \\
\text { wysoka (AW) } \\
\text { M(SD) } \\
\mathbf{n = 2 8}\end{array}$ & $\begin{array}{c}\text { Akceptacja } \\
\text { (cała grupa) } \\
\text { M(SD) } \\
\text { n=84 }\end{array}$ \\
\hline $\begin{array}{l}\text { Akceptacja siebie jako } \\
\text { osoby głuchej (\%) }\end{array}$ & $41,3(18,0)$ & $78,3(7,0)$ & $97,9(1,0)$ & $74,51(25,0)$ \\
\hline Zakres (min - maks) (\%) & $5-61$ & $65-90$ & $94-100$ & $5-100$ \\
\hline $\begin{array}{l}\text { Test Shapiro - } \\
\text { normalność rozkładu } \\
\text { wyników (p) }\end{array}$ & $\begin{array}{c}\text { Nie } \\
0,00\end{array}$ & $\begin{array}{c}\text { Tak } \\
0,18\end{array}$ & $\begin{array}{c}\text { Nie } \\
0,04\end{array}$ & $\begin{array}{c}\text { Nie } \\
0,00\end{array}$ \\
\hline
\end{tabular}

$\mathrm{n}$ - liczebność grupy; $\mathrm{M}$ - średnia; SD - odchylenie standardowe; $\mathrm{p}$ - poziom istotności

Rezultaty porównań wyników (ANOVA) w trzech grupach o akceptacji siebie jako osoby głuchej: niskiej, średniej i wysokiej ze względu na zmienne socjodemograficzne (płeć, wiek, status małżeński/partnerski) i związane z głuchotą i CI (wiek w momencie CI, czas korzystania z CI, znajomość języka migowego) pokazują, że nie ma różnic istotnych statystycznie pod względem wymienionych zmiennych, a więc grupy o różnym poziomie akceptacji siebie jako osoby głuchej są pod tym względem do siebie podobne.

Tożsamość osobista (Kwestionariusz „Ja-Inni”) a akceptacja siebie jako osoby głuchej (VAS)

W celu odpowiedzi na pytanie o istnienie zależności między tożsamością osobistą i akceptacją siebie jako osoby głuchej dokonano porównania wyodrębnionych trzech grup o stopniu akceptacji siebie niskim (AN), średnim 
(AS) i wysokim (AW) (ANOVA, test chi Kruskala). Wyniki zostały przedstawione w tabeli 3 .

Tabela 3. Tożsamość osobista (Kwestionariusz „Ja-Inni”) a akceptacja siebie jako osoby głuchej (AN - niska, AS - średnia, AW - wysoka) - wyniki porównań istotne statystycznie: $\mathrm{p}<0,05$.

\begin{tabular}{lcccc}
\hline $\begin{array}{l}\text { Tożsamość osobista (Kwestionariusz } \\
\text { „Ja-Inni”) }\end{array}$ & $\begin{array}{c}\text { ANOVA } \\
\mathbf{( F )}\end{array}$ & $\mathbf{p}$ & Kruskal chi & p \\
\hline Nieśmiały & 10,34 & 0,000 & 16,56 & 0,000 \\
Samotny & 7,42 & 0,001 & 12,52 & 0,002 \\
Słaby & 7,42 & 0,014 & 8,01 & 0,018 \\
\hline Cechy negatywne ogólem & 3,72 & 0,031 & 7,75 & 0,021 \\
\hline
\end{tabular}

Następnie do porównań w parach poszczególnych grup o akceptacji siebie jako osoby głuchej: AN, AS, AW pod względem istotnych różnic między nimi otrzymanych w Kwestionariuszu „Ja-Inni” dla takich cech, jak: „nieśmiały”, „samotny”, „słaby” i cechy negatywne razem, wykorzystano testy post hoc zgodnie z procedurą Tukey Honestly Significant Difference (test rzeczywiście znaczącej różnicy Tukeya). Wyniki zaprezentowano w tabeli 4 . Okazuje się, że przede wszystkim znacząco różnią się miedzy sobą pod względem percepcji siebie jako „nieśmiałego”, „samotnego”, „słabego” i cech negatywnych razem osoby należące do grup o niskim (AN) i wysokim (AW) poziomie akceptacji siebie jako osoby głuchej (tabela 4).

Tabela 4. Kwestionariusz „Ja-Inni” (cechy: „nieśmiały”, „,samotny”, „słaby” oraz cechy negatywne razem) - porównania post hoc między grupami o trzech stopniach akceptacji siebie jako osoby głuchej: (AN - akceptacja niska, AS - akceptacja średnia, AW - akceptacja wysoka).

\begin{tabular}{|c|c|c|}
\hline \multirow{2}{*}{ Kwestionariusz „,Ja-Inni” (cechy) } & $\begin{array}{c}\text { Akceptacja siebie jako osoby } \\
\text { głuchej - porównywane grupy } \\
\text { AN, AS, AW } \\
\text { (testy post hoc Tukeya) }\end{array}$ & $\mathbf{p}$ \\
\hline \multirow{2}{*}{ Nieśmiały } & $\mathrm{AN}-\mathrm{AS}$ & $\mathrm{p}=0,863$ \\
\cline { 2 - 3 } & $\mathrm{AN}-\mathrm{AW}$ & $\mathbf{p}=\mathbf{0 , 0 0 0}$ \\
\cline { 2 - 3 } & $\mathrm{AW}-\mathrm{AS}$ & $\mathbf{p}=\mathbf{0 , 0 0 1}$ \\
\hline
\end{tabular}




\begin{tabular}{|c|c|c|}
\hline \multirow{4}{*}{ Samotny } & AN - AS & $\mathbf{p}=\mathbf{0 , 0 2 4}$ \\
\cline { 2 - 3 } & AN - AW & $\mathbf{p}=\mathbf{0 , 0 0 0}$ \\
\cline { 2 - 3 } & AW - AS & $\mathrm{p}=0,378$ \\
\hline \multirow{4}{*}{ Słaby } & AN - AS & $\mathrm{p}=0,612$ \\
\cline { 2 - 3 } & $\mathrm{AN}-\mathrm{AW}$ & $\mathbf{p}=\mathbf{0 , 0 1 2}$ \\
\cline { 2 - 3 } & $\mathrm{AW}-\mathrm{AS}$ & $\mathrm{p}=0,094$ \\
\hline \multirow{3}{*}{ Cechy negatywne razem } & $\mathrm{AN}-\mathrm{AS}$ & $\mathrm{p}=0,275$ \\
\cline { 2 - 3 } & $\mathrm{AN}-\mathrm{AW}$ & $\mathbf{p}=\mathbf{0 , 0 1 3}$ \\
\cline { 2 - 3 } & $\mathrm{AW}-\mathrm{AS}$ & $\mathrm{p}=0,318$ \\
\hline
\end{tabular}

$\mathrm{p}$ - poziom istotności statystycznej

Uwaga: podkreślono na Wykresie 1 cechy istotnie różne ze względu na wyróżniony poziom akceptacji siebie jako osoby głuchej.

\section{DYSKUSJA}

W artykule zaprezentowano badania nad tożsamością osobistą dorosłych osób prelingwalnie głuchych, użytkowników jednego lub dwóch implantów ślimakowych (CI) - dość rzadko będącej przedmiotem badań empirycznych w porównaniu do badań nad tożsamością społeczno-kulturową osób g/Głuchych - i jej związkiem z akceptacją siebie jako osoby głuchej.

W tożsamości osobistej badanej grupy osób dorosłych z głuchotą prelingwalną dominuje polaryzacja pozytywna: osoby głuche z CI przypisują sobie większe nasilenie cech pozytywnych niż negatywnych, analogicznie jak w innych badaniach i podobnie jak w populacji ogólnej (Kobosko, 2007a, 2009). Największa rola spośród przypisywanych sobie atrybutów pozytywnych, odróżniających je od innych, przypada cechom o wysokim nasileniu takim, jak: „wrażliwy” i „dobry”, jak i cechom o niskim nasileniu: „słyszący” i „głupi”. Doświadczanie siebie jako „wrażliwego” i „dobrego”, a także jako w niewielkim stopniu „słyszącego" i „głupiego” stanowi wyróżniające wymiary osobistej tożsamości. Nie wiadomo jednak, na ile ważne są to cechy w percepcji badanych, by uznać je za cechy schematowe (Markus, 1992; za: Jarymowicz, Szuster, 2015). Bardzo podobne rezultaty otrzymano ponad dekadę temu w badaniach tożsamości osobowej młodzieży głuchej porozumiewającej się w języku polskim fonicznym z zastosowaniem tego samego pomiaru (Kobosko, 2007a, 2009). Można więc sądzić, że tożsamość osobista, opisana powyżej wskazanymi atrybutami odróżniającymi osoby głuche 
od innych ludzi, nie uległa zasadniczo zmianie $w$ tej populacji, jak i nie wiąże się w tym aspekcie z korzystaniem z CI (w przywoływanych badaniach nad młodzieżą głuchą tylko jedna osoba była użytkownikiem implantu ślimakowego). Można zatem uznać, że tożsamość osobista osób z głuchotą prelingwalną charakteryzuje się pewną stabilnością wyrażoną $\mathrm{w}$ percepcji siebie $\mathrm{w}$ kategoriach cech $\mathrm{w}$ porównaniu $\mathrm{z}$ innymi ludźmi. Odpowiedź na pytanie, na ile tożsamość osobista pozostaje specyficzna ze względu na głuchotę, dałyby badania porównawcze osób reprezentujących populację ogólną.

Akceptacja siebie jako osoby głuchej (VAS) pozostaje w zależności z tożsamością osobistą (Kwestionariusz Ja-Inni) w zakresie cech: „nieśmiały”, „samotny”, „słaby” i wszystkich cech negatywnych razem. Oznacza to, że mniejsza akceptacja siebie wykazuje związek z percepcją siebie jako bardziej „nieśmiałego”, „samotnego”, „słabego” i posiadającego większe nasilenie cech negatywnych ogółem w porównaniu z innymi ludźmi. Jak wiadomo z badań, zarówno jakościowych, jak i ilościowych, młodzież głucha i dorosłe osoby głuche doświadczają trudności w sferze relacji z innymi ludźmi, zarówno relacji rodzinnych, w tym intymnych, a także rówieśniczych (Krawiec, 2009; Kobosko, 2009, 2010; Levinger, Ronen, 2010; Podgórska-Jachnik, 2013; Dryżałowska, 2016; Wrześniewska-Pietrzak, 2017). Przejawiają się one w doświadczaniu ograniczeń w nawiązywaniu relacji z innymi (,nieśmiały"), a w konsekwencji samotności i poczucia osamotnienia (,samotny”), a także ogólnie w negatywnych przekonaniach na swój temat (cechy negatywne ogółem), co wskazuje pośrednio na obniżoną samoocenę (Kobosko, Jędrzejczak, Gos, Geremek-Samsonowicz, Ludwikowski, Skarżyński, 2018). Uwarunkowań rozwoju tożsamości osób głuchych i akceptacji siebie jako osoby głuchej należy poszukiwać w relacjach rodzinnych i rówieśniczych, szerzej środowiskowych (Orth, 2017; Zalewska, 1998). Problemy związane $\mathrm{z}$ akceptacją siebie jako osoby głuchej na ogół współwystępują z trudnościami związanymi z tożsamością osobistą, zwłaszcza jako osoby głuchej (Zalewska, 1998, 2009a, 2009b). Osoba głucha (której rodzice są słyszący i doświadczają lub doświadczali trudności związanych z włączeniem głuchoty dziecka w swoją rodzicielską tożsamość) „nie mogąc przeżyć rozpaczy, może jedynie «pogodzić się» z tym, że jest głucha, to znaczy mieć głuchotę w sobie jak ciało obce, którego nie potrafi włączyć we własną tożsamość i tak ją zreorganizować, aby mogła być sama dla siebie i dla innych osobą głuchą" - pisze Marina Zalewska (2009b, s. 265). I dalej dodaje, że ci młodzi głusi ludzie, którzy nie mogli podzielać z matką (lub inną znaczącą osobą - przyp. aut.) swych przeżyć wokół głuchoty, nie mieli z psycholo- 
gicznego punktu widzenia warunków przyjęcia jej jako elementu własnego osobowego wyposażenia. W myśl podejścia interpersonalnego sytuacja taka wiąże się zazwyczaj z doświadczaniem przez słyszące matki trudności w stawaniu się matkami swoich głuchych dzieci (Zalewska, 1998).

Otrzymane rezultaty pokazują, jak ważna jest akceptacja siebie jako osoby głuchej w osiąganiu tożsamości osobistej związanej z funkcjonowaniem w sferze relacji z innymi ludźmi, lecz nie bezpośrednio z samym słyszeniem (doświadczanie siebie w wymiarze/cesze „słyszący”, jak i też z wymiarami poznawczymi tożsamości osobistej, reprezentowanymi przez cechy takie, jak np.: „głupi” czy „pomysłowy” pozostaje niezwiązane z akceptacją siebie jako osoby głuchej). Ponadto zwraca uwagę, że bardzo wysoka akceptacja siebie, stuprocentowa lub bliska tej wartości, cechuje znaczną liczbę uczestników badań (33\%), dokonujących własnej oceny w omawianym wymiarze. Można postawić w tym miejscu hipotezę do dalszej empirycznej weryfikacji, że wśród nich są także osoby z zaburzeniami narcystycznymi, u których mamy do czynienia m.in. z wysoką samooceną jawną, dostępną świadomości, a niską samooceną utajoną, która pozostaje niedostępna świadomości (Greenwald, 1986; za: Porębiak, 2005). Hipoteza ta znajduje swoje uzasadnienie nie tylko teoretyczne, nawiązując do istnienia wysokiej samooceny jawnej i niskiej samooceny ukrytej właśnie w zaburzeniach narcystycznych (Johnson, 1993), lecz także kliniczne: to narcystyczna osobowość - zdaniem Mariny Zalewskiej - należy do specyficznych problemów rozwojowych dziecka głuchego (słyszących rodziców) będących wyrazem zaburzeń rozwoju jego osobowej tożsamości (Zalewska, 1998, s. 94).

Ograniczeniem badań jest duże zróżnicowanie osób w nich uczestniczących pod względem wieku, w jakim zostały zaopatrzone w jeden lub dwa implanty ślimakowe, a tym samym czasu korzystania z tych elektronicznych urządzeń wzmacniających słyszenie. Jednakże należy podkreślić, że kryterium zasadnicze doboru osób do badań stanowił ubytek słuchu w stopniu znacznym lub głębokim (kryterium „społecznej głuchoty”) wraz z wysokimi kompetencjami językowymi w języku polskim fonicznym, a także fakt korzystania $\mathrm{z}$ implantu ślimakowego będącego jednym $\mathrm{z}$ tożsamościowych „wyróżników” osób głuchych (Kobosko, Pankowska, Geremek-Samsonowicz, Skarżyński, 2018; Leigh, 2009).

Przeprowadzone badania sugerują, że należałoby wspierać osoby głuche, także te zaopatrzone w implanty ślimakowe i komunikujące się biegle w języku polskim fonicznym w tym, aby ,dawały sobie prawo do bycia sobą takimi, jakie są" (bowiem 30\% osób badanych cechuje niska akceptacja siebie 
jako osoby głuchej), a więc doświadczające trudności w akceptacji siebie jako osoby głuchej i/lub w sferze relacji interpersonalnych, co podkreślają otrzymane rezultaty badań. Wskazane jest stworzenie oferty adresowanej do tej grupy osób obejmującej różne formy interwencji psychologicznej, łącznie z psychoterapią indywidualną lub grupową, treningami interpersonalnymi czy treningami asertywności. Z kolei realizacja postulatu psychologicznego wsparcia dzieci głuchych i ich rodzin od wczesnych lat życia pozwoli m.in. na rozwój kompetencji społecznych osób głuchych (Kobosko, 2017) czy ułatwi rodzicom stawanie się rodzicami swoich głuchych dzieci (Zalewska, 1998, 2009a, 2009b). Ciekawym byłoby także podjęcie badań nad związkiem tożsamości osobistej $\mathrm{z}$ akceptacją siebie jako osoby głuchej w populacji osób Głuchych, które komunikują się w polskim języku migowym, jak i identyfikują ze społecznością Głuchych.

\section{BIBLIOGRAFIA}

CArter, M.J., Mireles, D.C. (2016). Deaf identity and depression. W: J.E. Stets, R.T. Serpe (red.), New Directions in Identity Theory and Research (s. 509-538). Oxford: Oxford University Press.

Chapman, M., Dammeyer, J. (2017). The significance of deaf identity for psychological well-being. Journal of Deaf Studies and Deaf Education, 22, 187-194.

DRYŻAŁOWSKA, G. (2016). Integracja edukacyjna a integracja społeczna. Satysfakcja z życia osób niedostyszacych. Warszawa: Wydawnictwa Uniwersytetu Warszawskiego.

Dzwonkowska, I., Lachowicz-Tabaczek, K., Łaguna, M. (2008). Samoocena i jej pomiar. Polska adaptacja skali SES M. Rosenberga. Warszawa: Pracownia Testów Psychologicznych.

DE GRAAF, R., BIJL, R.V. (2002). Determinants of mental distress in adults with a severe auditory impairment: differences between prelingual and postlingual deafness. Psychosomatic Medicine, 64, 61-70.

JARymowicz, M., Szuster, A. (2015). Rozmowy o rozwoju osobowym. Od koncentracji na sobie i swoich do otwartości na świat i altruizm. Warszawa: Wydawnictwa Uniwersytetu Warszawskiego.

Johnson, S. (1993). Humanizowanie narcystycznego stylu, thum. A. Czownicka. Warszawa: J. Santorski \& CO Agencja Wydawnicza.

Koвosko, J. (2007a). Tożsamość macierzyńska słyszących matek młodzieży głuchej i jej znaczenie dla rozwoju osobowej tożsamości tej młodzieży. Nieopublikowana rozprawa doktorska. Warszawa: Uniwersytet Warszawski.

Koвosko, J. (2007b). Co to znaczy być osobą głuchą? Studia nad tożsamością osobową młodzieży głuchej ze słyszących rodzin. W: E. WoźNICKA (red), Tożsamość społeczno-kulturowa gluchych (s. 33-51). Łódź: Wydawnictwa WSHE w Łodzi, PZG Oddział Łódzki.

Koвosкo, J. (2009). Osoba głucha (słabosłysząca), to znaczy kto? - tożsamość osobowa młodzieży głuchej i słabosłyszącej rodziców słyszących. W: J. Kовоsко (red.), Młodzież głucha 
i słabostysząca $w$ rodzinie i otaczającym świecie - dla terapeutów, nauczycieli, wychowawców i rodziców (s. 19-35). Warszawa: Stowarzyszenie „Usłyszeć Świat”.

Koвosko, J. (2010). Doświadczanie siebie jako osoby głuchej - badania nad młodzieżą głuchą i jej słyszącymi matkami z perspektywy interpersonalnej. Człowiek - Niepelnosprawność Spoleczénstwo, 11, 101-122.

Ковоsко, J. (2017). Wspieranie rozwoju kompetencji społecznych u dzieci głuchych i słabo słyszących. W: A. JEGIER, B. SzUROWSKA (red.), Umiejętności społeczne dzieci. Ksztattowanie rozwoju emocjonalno-spolecznego dzieci w normie rozwojowej i dzieci ze specjalnymi potrzebami edukacyjnymi (s. 81-103). Warszawa: Dilfin.

Koвosko, J. (2018). Samoocena u osób dorosłych z głuchotą prelingwalną korzystających z implantu ślimakowego. W: K. PARYs, M. TROJAŃSKA, A. OCHMAN (red.), Teoria i praktyka oddziaływań profilaktyczno-wspierajacych rozwój osób z niepetnosprawnościa - wobec pytań i odpowiedzi o dobrostan człowieka (s. 46-61). Kraków: Wydawnictwo Uniwersytetu Pedagogicznego.

Kobosko, J., Geremek-Samsonowicz, A., Kochański, B., Pankowska, A., Skarżyński, H. (2019). Akceptacja siebie jako osoby głuchej a subiektywna ocena korzyści i satysfakcji $\mathrm{z}$ implantu ślimakowego u osób dorosłych z głuchotą prelingwalną. Nowa Audiofonologia, 8(4), 22-31.

Kobosko, J., Jędrzejczak, W.W, Gos, E., Geremek-SAmsonowicz, A., Ludwikowski, M., SKARZYŃSKI, H. (2018). Self-esteem in the deaf who have become cochlear implant users as adults. PLoS ONE, 13(9): e0203680. https://doi.org/10.1371/journal.pone.0203680.

Kobosko, J., Pankowska, A., Geremek-Samsonowicz, A., SkarżyŃski, H. Implant ślimakowy z perspektywy osób dorosłych z głuchotą prelingwalną - badanie jakościowe. Nowa Audiofonologia, 7(3), 27-41.

Kobosko, J., Szuchnik, J., WojdA, P. (2004). Kwestionariusz Ja-Inni jako narzędzie służące do opisu tożsamości własnej młodzieży głuchej. Audiofonologia, 26, 119-133.

Kossewska, J., Brdej, K. (2008). Personal identity in deaf adolescents. Journal of Special Education and Rehabilitation, 9, 67-75.

KRAWIEC, M. (2009). Poczucie niepełnosprawności u młodzieży z uszkodzeniami narządu słuchu. W: J. Kовоsко (red), Młodzież głucha i słabostyszaca w rodzinie i otaczajacym świecie - dla terapeutów, nauczycieli, wychowawców i rodziców (s. 67-78). Warszawa: Stowarzyszenie „Usłyszeć Świat”.

KWAPIS, K., BRYGOŁA, E. (2013). Tożsamość osobista w ujęciu emotywno-refleksyjnym: zawartość, funkcje i procesy kształtowania tożsamości. Opuscula Sociologica, 18, 33-49.

KRZYŻEWSKI, K., KAZBERUK, A. (2000). Specyfika psychologicznego ujmowania tożsamości. W: A. GaŁdowa (red.), Tożsamość czlowieka (s. 17-34). Kraków: Wydawnictwo Uniwersytetu Jagiellońskiego.

LeIGH, I.W. (2009). A lens on deaf identities. Oxford, New York: Oxford University Press.

Leigh, I.W. (2010). Reflections on identity. W: M. MARSChARK, P.E. SPEnCER (red.), The Oxford handbook of deaf studies, language, and education, t. 2 (s. 195-209). Oxford: Oxford University Press.

LEVIngER, M., Ronen, T. (2010). The link among self-esteem, differentiation, and spousal intimacy in deaf and hearing adults. Journal of Social Work in Disability and Rehabilitation, 9, $27-52$. 
LI, L., Moore, D. (1998). Acceptance of disability and its correlates. Journal of Social Psychology, 138, 13-25.

Marganiec, B. (2014). Kultura Głuchych. W: M. ŚWIDZIŃSKI (red.), Sytuacja osób głuchych w Polsce. Raport zespolu ds. g/Gluchych przy Rzeczniku Praw Obywatelskich (s. 137-157). Warszawa: RPO.

Marschark, M., Zettler, I., Dammeyer, J. (2017). Social dominance orientation, language orientation, and deaf identity. Journal of Deaf Studies and Deaf Education, 22, 269-277.

OrTh, U. (2017). The lifespan development of self-esteem. W: J. SPECHT (red.), Personality development across the lifespan (s. 181-195). London: Elsevier.

PodGóRSKA-JACHNIK, D. (2013). Głusi. Emancypacje. Łódź: Wydawnictwo Naukowe Wyższej Szkoły Pedagogicznej w Łodzi.

PoręBIAK, M. (2005). Samoocena jawna i utajona. Model dwuskładnikowy. Nowiny Psychologiczne, 2, 93-106.

WoJdA, P. (2010). Język migowy a tożsamość społeczno-kulturowa młodzieży głuchej w Polsce. Audiofonologia, 26, 29-33.

Wolsel, J.L.A., ClARK, M.D.L., VAN DER MARK, S.C. (2017). Life scripts and life stories of oral deaf individuals. Journal of Developmental and Physical Disabilities, 29, 77-103.

WRZEŚNIEWSKA-PIETRZAK, M. (2017). Aksjologiczne wyznaczniki tożsamości w wypowiedziach gluchych i czasopiśmie środowiskowym „Świat Ciszy”. Poznań: Wydawnictwo Rys.

ZAlEwSKA, M. (1998). Dziecko $w$ autoportrecie z zamalowana twarza. Psychiczne mechanizmy zaburzeń rozwoju tożsamości dziecka gluchego i dziecka z opóźnionym rozwojem mowy. Warszawa: Jacek Santorski i CO Wydawnictwo.

ZALEWSKA, M. (2009a). Mechanizmy zaburzeń tożsamości u młodzieży głuchej mającej słyszących rodziców - kliniczne studium głuchego chłopca. W: J. Kовоsко (red.), Młodzież głucha i słabostyszaca $w$ rodzinie $i$ otaczajacym świecie - dla terapeutów, nauczycieli, wychowawców i rodziców (s. 78-83). Warszawa: Stowarzyszenie „Usłyszeć Świat”.

ZALEWSKA, M. (2009b). „Samotność wśród bliskich” - kliniczne studium Krystyny, dziewczyny głuchej przeżywającej problemy wokół własnej tożsamości. W: J. KoвosKo (red.), Młodzież glucha i stabostyszaca $w$ rodzinie i otaczajacym świecie - dla terapeutów, nauczycieli, wychowawców i rodziców (s. 261-266). Warszawa: Stowarzyszenie „Usłyszeć Świat”.

ZĘBIK, J. (2007). Tożsamość osoby zaimplantowanej - czyli o sobie. W: E. WoźNicKA (red.), Tożsamość społeczno-kulturowa głuchych. (s. 233-249). Łódź: Wydawnictwa WSHE, PZG Oddział Łódzki.

\section{TOŻSAMOŚĆ OSOBISTA I JEJ ZWIĄZEK Z AKCEPTACJĄ SIEBIE JAKO OSOBY GŁUCHEJ - BADANIA NAD DOROSŁYMI UŻYTKOWNIKAMI IMPLANTÓW ŚLIMAKOWYCH Z GŁUCHOTĄ PRELINGWALNĄ}

\section{STRESZCZENIE}

Tożsamość osobista, także w aspekcie doświadczania siebie jako osoby głuchej, ma ogromne znaczenie dla zdrowia psychicznego osób głuchych. W pracy postawiono pytanie o jej związek $\mathrm{z}$ akceptacją siebie jako osoby głuchej. Badaniami objęto 84 osoby $\mathrm{z}$ głuchotą prelingwalną i z implantem ślimakowym (CI), o wysokich kompetencjach językowych w języku polskim fonicznym, w wieku od 18 do 45 lat. Do opisu tożsamości osobistej wykorzystano Kwestionariusz Ja-Inni, 
a do oceny akceptacji siebie jako osoby głuchej posłużono się skalą typu VAS. Okazało się, że tożsamość osobistą osób prelingwalnie głuchych z CI odróżniają od innych cechy w ich percepcji o największym nasileniu, tj. „wrażliwy” i „dobry”, a także o najmniejszym nasileniu, tj. „słyszący” i „głupi”. Wraz z niższą akceptacją siebie, jako osoby głuchej, należy spodziewać się doświadczania siebie w relacjach z innymi ludźmi jako bardziej „nieśmiałego”, „samotnego” i „słabego", a także posiadającego większe nasilenie cech negatywnych ogółem. Właściwości te stają się ważnymi wyróżnikami w tożsamości osobistej jako osoby głuchej u objętych badaniami osób $\mathrm{z}$ głuchotą prelingwalną.

Słowa kluczowe: tożsamość osobista osób głuchych; akceptacja siebie jako osoby głuchej; głuchota prelingwalna; implant ślimakowy.

\title{
PERSON IDENTITY AND ITS RELATION WITH THE SELF-ACCEPTANCE AS A DEAF PERSON - STUDIES ON THE PRELINGUALLY DEAF ADULTS USING COCHLEAR IMPLANTS
}

\begin{abstract}
SUMMARY
Person identity, also in the aspect of experiencing the self as a deaf person, plays a vital role in the mental health of deaf and hard-of-hearing people. The aim of the present study is to examine its relation with the self-acceptance as a deaf person. The study involved 84 people with prelingual deafness who underwent cochlear implantation with high competencies in the Polish phonic language aged between 18 and 45. The I-Others questionnaire was used to describe a person identity. The self-acceptance was measured using the VAS-type scale. Person identity of the prelingually deaf CI users is differentiated from others by characteristics perceived by them to be the strongest, such as "sensitive" or "good", or the weakest, such as "hearing" or "stupid". It turned out that alongside lower self-acceptance as a deaf person we can expect the perception of self as more "shy", "lonely", or "weak" in interpersonal relations, as well as possessing higher intensity of negative traits overall. These attributes are important characteristics of person identity as a deaf person.
\end{abstract}

Keywords: deaf person identity; self-acceptance as a deaf person; prelingual deafness; cochlear implant. 